\title{
Narwhals document continued warming of southern Baffin Bay
}

\author{
K. L. Laidre, ${ }^{1,2}$ M. P. Heide-Jørgensen, ${ }^{2}$ W. Ermold, ${ }^{1}$ and M. Steele ${ }^{1}$ \\ Received 18 September 2009; revised 18 May 2010; accepted 15 June 2010; published 23 October 2010.
}

[1] We report on wintertime data collected from Baffin Bay and northern Davis Strait, a major gateway linking the Arctic with the subpolar North Atlantic, using narwhals (Monodon monoceros) as an oceanographic sampling platform. Fourteen narwhals were instrumented with satellite-linked time-depth-temperature recorders between 2005 and 2007. Transmitters collected and transmitted water column temperature profiles from each dive between December and April, where $>90 \%$ of maximum daily dive depths reached the bottom. Temperature measurements were combined with 15 helicopter-based conductivity-temperature-depth (CTD) casts taken in April 2007 across central Baffin Bay and compared with hydrographic climatology values used for the region in Arctic climate models. Winter temperature maxima for whale and CTD data were in good agreement, ranging between $4.0^{\circ} \mathrm{C}$ and $4.6^{\circ} \mathrm{C}$ in inshore and offshore Baffin Bay and in Davis Strait. The warm Irminger Water was identified between $57^{\circ} \mathrm{W}$ and $59^{\circ} \mathrm{W}$ (at $68^{\circ} \mathrm{N}$ ) between 200 and $400 \mathrm{~m}$ depths. Whale data correlated well with climatological temperature maxima; however, they were on average $0.9^{\circ} \mathrm{C}$ warmer $\pm 0.6^{\circ} \mathrm{C}(P<0.001)$. Furthermore, climatology data overestimated the winter surface isothermal layer thickness by $50-80 \mathrm{~m}$. Our results suggest the previously documented warming in Baffin Bay has continued through 2007 and is associated with a warmer West Greenland Current in both of its constituent water masses. This research demonstrates the feasibility of using narwhals as ocean observation platforms in inaccessible Arctic areas where dense sea ice prevents regular oceanographic measurements and where innate site fidelity, affinity for winter pack ice, and multiple daily dives to $>1700 \mathrm{~m}$ offer a useful opportunity to sample the area.

Citation: Laidre, K. L., M. P. Heide-Jørgensen, W. Ermold, and M. Steele (2010), Narwhals document continued warming of southern Baffin Bay, J. Geophys. Res., 115, C10049, doi:10.1029/2009JC005820.

\section{Introduction}

[2] Baffin Bay is a large semi-enclosed basin adjacent to the North American continent with a maximum depth of approximately $2500 \mathrm{~m}$. The bay extends southward into Davis Strait and is bordered on the west by Baffin Island, Canada, and on the east by Greenland. The waters of southeastern Baffin Bay are mainly influenced by waters from the south [Smith et al., 1937; Bourke et al., 1989] that flow northward on the shelf and the slope, referred to as the West Greenland Current (WGC). On the Greenland shelf, the WGC is composed of relatively fresh and cold northward-flowing water, referred to as the West Greenland Shelf Water (WGSW). This is a remnant of the fresh Arctic Ocean outflow that flows southward along the East Greenland shelf, freshening in summer from sea ice melt and continental runoff as it transits around the southern tip of Greenland and then northward into Baffin Bay. On the slope, the WGC is a

\footnotetext{
${ }^{1}$ Polar Science Center, Applied Physics Laboratory, University of Washington, Seattle, Washington, USA.

${ }^{2}$ Greenland Institute of Natural Resources, Nuuk, Greenland.

Copyright 2010 by the American Geophysical Union. 0148-0227/10/2009JC005820
}

mixture of deeper Arctic Ocean outflows combined with warmer water from the North Atlantic and Irminger Sea Water that together are commonly referred to as Irminger Water (IW). The IW forms a temperature maximum at several hundred meters depth that cools along its northern pathway on the West Greenland slope [Myers et al., 2007, 2009; Tang et al., 2004].

[3] Mounting evidence of ocean warming on the banks of West Greenland [Holland et al., 2008; Myers et al., 2009] indicates that cascading changes in the ecosystem can be expected and some are already documented [HeideJørgensen et al., 2009; Laidre et al., 2009]. Zweng and Münchow [2006] used historical and essentially only summertime data to examine evidence of warming in Baffin Bay and Davis Strait between 1920 and 2003. The deep basin temperatures exhibited a statistically significant warming at depths between 400 and $2400 \mathrm{~m}$ with maximum warming as large as $0.2^{\circ} \mathrm{C}$ per decade observed between 600 and $800 \mathrm{~m}$ [Zweng and Münchow, 2006]. This warming was attributed to enhanced advection of warm North Atlantic water from south of Davis Strait along the West Greenland slope and into the deep basin of Baffin Bay. This warming was primarily detected after 1950 , but the scarcity of data pre- 1950 impeded evaluation of a longer time series [Zweng and Münchow, 2006]. 
Table 1. Information on 14 Narwhals Instrumented With Satellite-Linked Temperature Depth Transmitters in Canada (Baffin Island, Kakiak Point 2005) and Greenland (Melville Bay 2006 and 2007)

\begin{tabular}{|c|c|c|c|c|c|c|c|c|c|}
\hline PTT ID No. & Sex & Length (cm) & $\begin{array}{c}\text { Fluke } \\
\text { Width }(\mathrm{cm})\end{array}$ & $\begin{array}{c}\text { Tusk } \\
\text { Length }(\mathrm{cm})\end{array}$ & Locality & $\begin{array}{c}\text { Tagging } \\
\text { Date }\end{array}$ & $\begin{array}{c}\text { Date of } \\
\text { Last Position }\end{array}$ & $\begin{array}{l}\text { Duration } \\
\text { (days) }\end{array}$ & $\begin{array}{c}\text { Average Maximum } \\
\text { Daily Dive } \\
\text { Depth (m) (range) }\end{array}$ \\
\hline 20685 & Female & 360 & 82 & - & Kakiak & $8 / 14 / 05$ & $1 / 11 / 06$ & 150 & $928(63-1422)$ \\
\hline 20686 & Male & 483 & 104 & 194 & Kakiak & $8 / 14 / 05$ & $2 / 7 / 06$ & 177 & $940(125-1773)$ \\
\hline 20689 & Female & 360 & 86 & - & Kakiak & $8 / 17 / 05$ & $9 / 2 / 05$ & 16 & 375 (104-684) \\
\hline 37235 & Female & 358 & 80 & - & Kakiak & $8 / 17 / 05$ & $10 / 23 / 05$ & 67 & $452(67-773)$ \\
\hline 37236 & Female & 380 & 89 & - & Kakiak & $8 / 17 / 05$ & $12 / 25 / 05$ & 131 & $1005(123-1742)$ \\
\hline 37280 & Female & 380 & 89 & - & Kakiak & $8 / 17 / 05$ & $12 / 26 / 05$ & 133 & $739(113-1382)$ \\
\hline 37282 & Female & 364 & 90 & - & Kakiak & $8 / 17 / 05$ & $3 / 24 / 06$ & 219 & $966(85-1771)$ \\
\hline 37283 & Female & 390 & 91 & - & Kakiak & $8 / 21 / 05$ & $11 / 23 / 05$ & 94 & $847(311-1533)$ \\
\hline 3960 & Female & 372 & 110 & - & Melville & 9/9/06 & $3 / 11 / 07$ & 182 & $636(231-1184)$ \\
\hline 3964 & Male & 437 & 108 & 187 & Melville & $9 / 13 / 06$ & $4 / 3 / 07$ & 201 & $742(305-1327)$ \\
\hline 7618 & Female & 390 & 100 & - & Melville & $8 / 26 / 07$ & $2 / 13 / 08$ & 170 & $571(290-791)$ \\
\hline 6335 & Female & 420 & 100 & - & Melville & $9 / 3 / 07$ & $3 / 31 / 08$ & 209 & $848(259-1297)$ \\
\hline 3965 & Female & 390 & 99 & - & Melville & $9 / 4 / 07$ & $2 / 13 / 08$ & 161 & $804(531-1097)$ \\
\hline 7617 & Male & 490 & 110 & 185 & Melville & $9 / 4 / 07$ & $9 / 14 / 07$ & 7 & 631 (NA) \\
\hline
\end{tabular}

[4] Despite the critical importance of Baffin Bay and Davis Strait and the West Greenland Current to North Atlantic circulation, most oceanographic data have been collected during summer and fall when the area is ice-free [Stein, 2004, 2005; Buch et al., 2004; Ribergaard et al., 2008; Myers et al., 2009]. Dense pack ice restricts access by research vessels, and thus, almost no winter temperature measurements are available for assessing interannual and intraannual variability (Bedford Institute of Oceanography (http://www.mar.dfo-mpo.gc.ca/ science/ocean/database/data_query.html)). Given the paucity of wintertime data in this important area, we utilized a nontraditional biological platform to collect data in Baffin Bay and within the WGC in winter.

[5] Among the Arctic top predators that inhabit the Baffin Bay/Davis Strait pack ice in winter, the narwhal (Monodon monoceros) is perhaps the most conspicuous. They make extensive annual migrations from high Arctic summering grounds in West Greenland and high Arctic Canada to offshore wintering grounds, where $>70,000$ whales occupy dense pack ice between November and April [Koski and Davis, 1994; Innes et al., 2002; Heide-Jørgensen et al., 2002, 2010; Richard et al., 2010]. Narwhals make minimal horizontal movements on these wintering grounds and feed intensively on the bottom where a major portion of the annual energy intake is obtained [Laidre et al., 2003, 2004a, 2004b]. Narwhals are also among the deepest diving cetaceans in the world, with the deepest dives occurring in winter to $1800 \mathrm{~m}$, between 10 and 25 times per day [Laidre et al., 2003]. These dives last over $25 \mathrm{~min}$ (maximum durations unknown) and are nearly vertical (with vertical speeds of $\sim 2 \mathrm{~m} \mathrm{~s}^{-1}$ ) to maximize transport time given aerobic constraints to reach demersal prey [Laidre et al., 2003]. This behavioral feature makes the narwhal an excellent "ocean sampler," as deep vertical dives are ideal for repetitive depth and temperature casts. Narwhals also have a strong affinity for the Arctic offshore pack ice, an area where few oceanographic studies have been accomplished.

[6] Here we capitalized on this suite of behavioral features to collect rare wintertime temperatures in Baffin Bay using narwhals instrumented with satellite-linked data recorders that sampled depths and temperatures during dives in Baffin Bay. These measurements were verified and combined with springtime helicopter-based conductivity-temperature-depth (CTD) casts to examine the spatial structure of the deep- water temperatures in central Baffin Bay and to compare modern and historical temperature series. Additionally, data collected from narwhals during winter were compared with climatological values [Steele et al., 2001].

\section{Data and Methodologies}

[7] Fourteen narwhals were captured and instrumented with satellite-linked time-depth-temperature recorders in August 2005 on Baffin Island, Canada, and September 2006 and 2007 in Melville Bay, West Greenland (Table 1). Narwhals were captured in nets that were $50-150 \mathrm{~m}$ long and $10 \mathrm{~m}$ deep. Two $6 \mathrm{~mm}$ nylon pins were attached to the dorsal ridge where transmitters were mounted using $0.5-2 \mathrm{~mm}$ plastic-coated wires secured between two nylon bolts at each end of the pins. The procedure lasted approximately $30 \mathrm{~min}$ and was conducted with the whales held in the net between two inflatable boats [see Heide-Jørgensen et al., 2002, 2003; Dietz et al., 2008]. Whales were tagged in accordance with Animal Care guidelines at the University of Washington and under a research permit from the Government of Greenland.

[8] Continuous data collected from diving narwhals consisted of point measurements of depth and temperature at a resolution of $1 \mathrm{~m}$ and $0.1^{\circ} \mathrm{C}\left( \pm 0.05^{\circ} \mathrm{C}\right)$ with a measurement range of $-2.0^{\circ} \mathrm{C}$ and $+4.35^{\circ} \mathrm{C}$ together with daily geographic positions from ARGOS. Instruments were calibrated by the manufacturer (Wildlife Computers, Redmond, WA) before deployment at a series of depths between 0 and $1000 \mathrm{~m}$ and a series of temperatures between $2^{\circ} \mathrm{C}$ and $40^{\circ} \mathrm{C}$ in water baths (Polystats, Cole Parmer) with an electronic thermistor (Hart Scientific, accuracy of $\pm 0.002^{\circ} \mathrm{C}$ ). Temperature and locations were transmitted through ARGOS; hence, the instrumented narwhals did not need to be recaptured to obtain the data, and a postdeployment calibration was not possible. However, Simmons et al. [2009] reported on precalibration and postcalibration after field deployment of the same external temperature stalk (Wildlife Computers) for pinnipeds and demonstrated, there was no significant drift during the deployment period. Tags provided up to seven continuous months of data from each whale before falling off and lasted well into winter months. An average daily geographic location was calculated for each narwhal throughout the duration it was tracked using only good quality ARGOS locations 


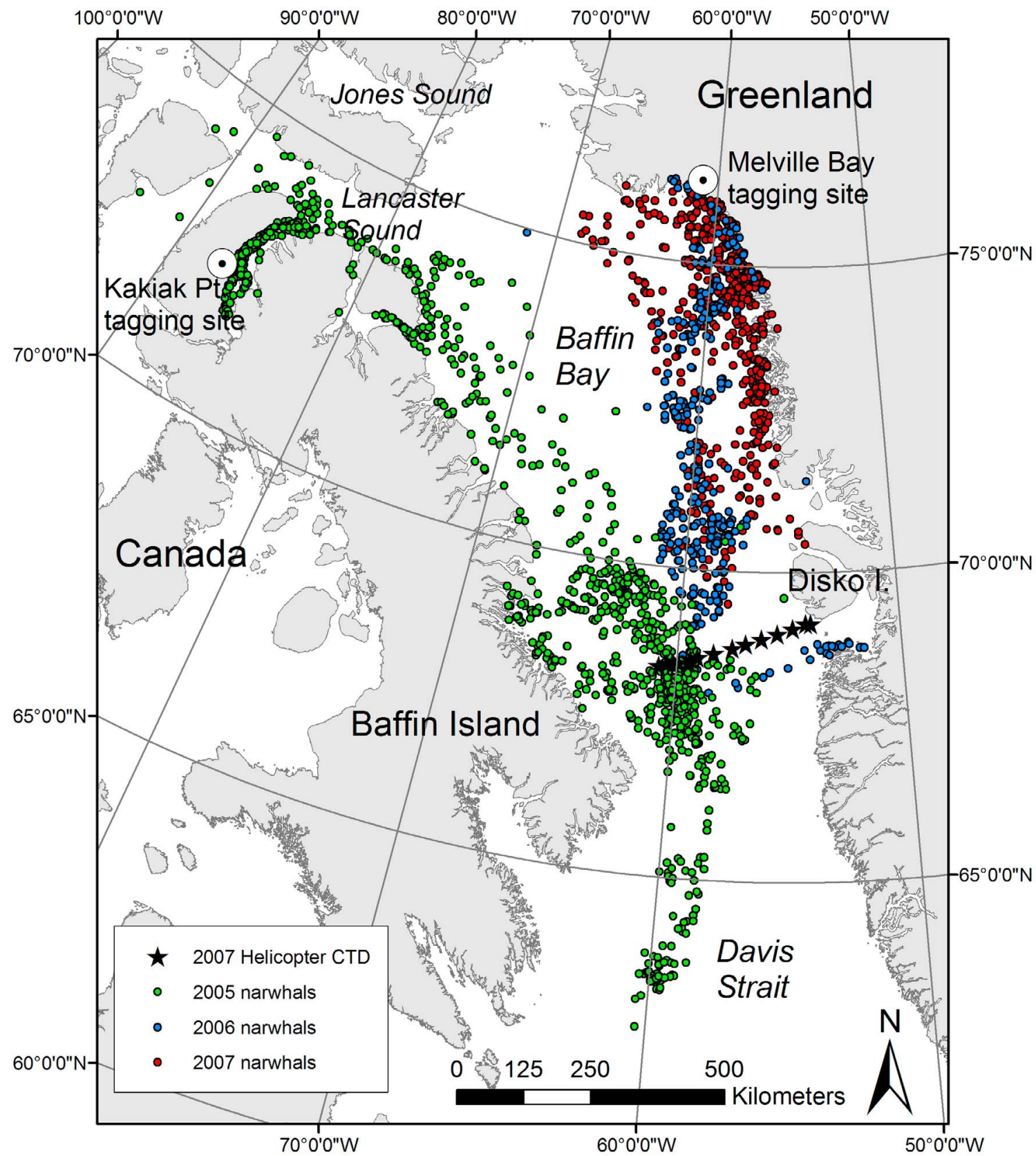

Figure 1. Map of average daily geographic positions of narwhals tagged with satellite-depth-temperature recorders between 2005 and 2007 together with the location of ship- and helicopter-based CTD casts in Baffin Bay. The box denotes the zoomed region displayed in Figures 2 and 3.

(LC 1-3) [Harris et al., 1990]. This geographic position was then linked to all depth-temperature pairs from the same day, and average daily profiles were created (hereafter referred to as "whale profiles"). Daily whale locations were linked to bathymetric depth in ArcGIS 9.3 (Environmental Science Research Institute) using the SRTM30_PLUS $30 \mathrm{~s}$ global topography grid [Becker et al., 2009]. The variation in the maximum daily dive depth across space and time was examined with respect to the bottom depth to determine the proportion of the water column sampled by the whales.

[9] Between 4 and 13 April 2007, a hydrographic temperature and salinity section was conducted from Disko
Island, West Greenland, in a west-southwest direction into the middle of Baffin Bay (Figure 1). Fifteen conductivitytemperature-depth (CTD) casts were made to $500 \mathrm{~m}$ depths using a SeaBird 19 Seacat CTD and lightweight winch. Light sea ice conditions meant that the two innermost of the 15 oceanographic stations had to be collected from a ship (RV Porsild, Arctic Station, University of Copenhagen). The outer 13 stations were collected from a helicopter (Air Greenland Bell 222) landing on large and stable ice floes. In most cases, a hole was drilled in sea ice to enable lowering of the CTD. Calibration was performed after deployment at Seabird Electronics; accuracies were estimated at 0.01 in 
Table 2. Number of Temperature Casts Made by Narwhals in Different Months With Sample Size ( $n$ Tagged Narwhals) Collecting Data ${ }^{a}$

\begin{tabular}{|c|c|c|c|c|c|}
\hline Month & Year & $n$ Unique Whales & $n$ Profiles & $\begin{array}{c}\text { Mean of Maximum } \\
\text { Profile Depth } \\
( \pm \text { Standard Deviation) }(\mathrm{m})\end{array}$ & $\begin{array}{c}\text { Percent of Water } \\
\text { Column Depth Traversed }\end{array}$ \\
\hline \multirow{2}{*}{ August } & 2005 & 6 & 14 & $768 \pm 259$ & $99 \%$ \\
\hline & 2007 & 1 & 1 & $589 \pm 0$ & $100 \%$ \\
\hline \multirow[t]{3}{*}{ September } & 2005 & 7 & 23 & $989 \pm 84$ & $100 \%$ \\
\hline & 2006 & 2 & 5 & $605 \pm 103$ & $100 \%$ \\
\hline & 2007 & 2 & 4 & $867 \pm 116$ & $100 \%$ \\
\hline \multirow[t]{3}{*}{ October } & 2005 & 6 & 31 & $1456 \pm 255$ & $85 \%$ \\
\hline & 2006 & 2 & 31 & $1282 \pm 172$ & $96 \%$ \\
\hline & 2007 & 3 & 31 & $1105 \pm 174$ & $100 \%$ \\
\hline \multirow{3}{*}{ November } & 2005 & 5 & 30 & $1773 \pm 334$ & $84 \%$ \\
\hline & 2006 & 2 & 30 & $1327 \pm 256$ & $65 \%$ \\
\hline & 2007 & 2 & 30 & $1290 \pm 178$ & $100 \%$ \\
\hline \multirow[t]{3}{*}{ December } & 2005 & 4 & 31 & $1771 \pm 337$ & $96 \%$ \\
\hline & 2006 & 2 & 31 & $1310 \pm 238$ & $87 \%$ \\
\hline & 2007 & 1 & 24 & $1297 \pm 146$ & $100 \%$ \\
\hline \multirow[t]{2}{*}{ January } & 2006 & 2 & 31 & $1705 \pm 320$ & $99 \%$ \\
\hline & 2007 & 2 & 31 & $1298 \pm 222$ & $99 \%$ \\
\hline \multirow[t]{3}{*}{ February } & 2006 & 1 & 27 & $1623 \pm 222$ & $91 \%$ \\
\hline & 2007 & 2 & 27 & $701 \pm 68$ & $99 \%$ \\
\hline & 2008 & 1 & 22 & $503 \pm 87$ & $100 \%$ \\
\hline \multirow[t]{3}{*}{ March } & 2006 & 1 & 23 & $1143 \pm 286$ & $72 \%$ \\
\hline & 2007 & 2 & 28 & $1293 \pm 345$ & $100 \%$ \\
\hline & 2008 & 1 & 29 & $1169 \pm 255$ & $100 \%$ \\
\hline April & 2007 & 1 & 2 & $736 \pm 0$ & $89 \%$ \\
\hline
\end{tabular}

${ }^{a}$ Data from fall (August-November) were not used in the comparative analysis with PHC data. The percent of the water column depth traversed by diving whales is based on the maximum seafloor depth in the vicinity of the whales for each month and year. One hundred percent denotes whales dove to the bottom.

both temperature and salinity. The hydrographic data were used to verify and calibrate nearby whale-based temperatures.

[10] The study area was divided up using a $100 \mathrm{~km}$ resolution Cartesian grid on a Polar Stereographic projection, which resulted in 27 grid cells or bins. All whale-based profiles in each bin were averaged for the months of December, January, February, and March to examine wintertime conditions in Baffin Bay. These binned data were compared with historical data obtained from the Bedford Institute of Oceanography and U.S. National Oceanographic Data Center, as presented in the Polar Science Center Hydrographic Climatology (PHC3.0, updated from Steele et al. [2001]). PHC was averaged in the same spatial bins as the whale-based profiles. Data were compared with regression techniques and significance was determined at the $P=0.05$ level.

\section{Results}

\subsection{Whale Data}

[11] Whale satellite transmitter longevity varied both within and across years. All whales tagged were adult $(>360 \mathrm{~cm}$ body length) with some males reaching nearly $5 \mathrm{~m}$ (Table 1). In 2005, the average duration of whale tracking was $123 \pm$ 64 days with a maximum duration of 219 days (data collected through $24 \mathrm{March}$ ). In 2006, the average duration of tracking was $192 \pm 13$ days with a maximum duration of 201 days (data collected to 3 April), and in 2007, the average duration was $137 \pm 89$ days with maximum tag longevity of 239 days (data were collected until 30 April) (Table 1).

[12] Maximum daily dive depths varied over the period whales were tracked. In general, maximum dive depths increased after departure from the summering grounds (when maximum dives were 600-800 m) and peaked in winter (where depths $>1600 \mathrm{~m}$ were regularly reached) (Table 2). The maximum dive depth reached by a whale in this study was $1773 \mathrm{~m}$. During the entire period, whales were tracked, on average $95 \% \pm 5.7 \%$ of whale dives reached the bottom (Figure 2a). This ranged between a high of $>99 \%$ of maximum daily dives reaching the bottom in summer months (August and September) to a low of $83 \%$ of maximum daily dives reaching the bottom during the November southbound migration (Table 2). In Baffin Bay in winter, $>90 \%$ of all daily maximum dive depths reached the bottom, indicating whales covered a large proportion of the water column while sampling temperatures. The maximum dive depth over 1 day was sometimes greater than the average daily ocean depth near the steep slope off the West Greenland shelf (Figure 2b).

[13] Spatial coverage, as obtained from narwhals tracked over 3 years, ranged over a significant portion of Baffin Bay. Whales tracked from Admiralty Inlet, Baffin Island, Canada, in 2005 remained on the west side of Baffin Bay and in winter were located between $63^{\circ} \mathrm{N}$ and $70^{\circ} \mathrm{N}$. Some whales from this population also ranged into Davis Strait. Whales tracked from Melville Bay, West Greenland, in 2006

Figure 2. (a) Daily geographic location of whales classified by maximum daily dive depth in Baffin Bay. Bathymetry contours are shown for reference. (b) Correlation between approximate daily bathymetric depth and maximum daily whale dive depth. Note, many dives occurred on the steep slope (500-1500 m) leading into the Baffin Bay abyss, and therefore, some maximum daily dive depths exceeded the bathymetry depth assigned for a given day. Over $90 \%$ of the maximum daily dives reached the bottom depth in Baffin Bay. 




b

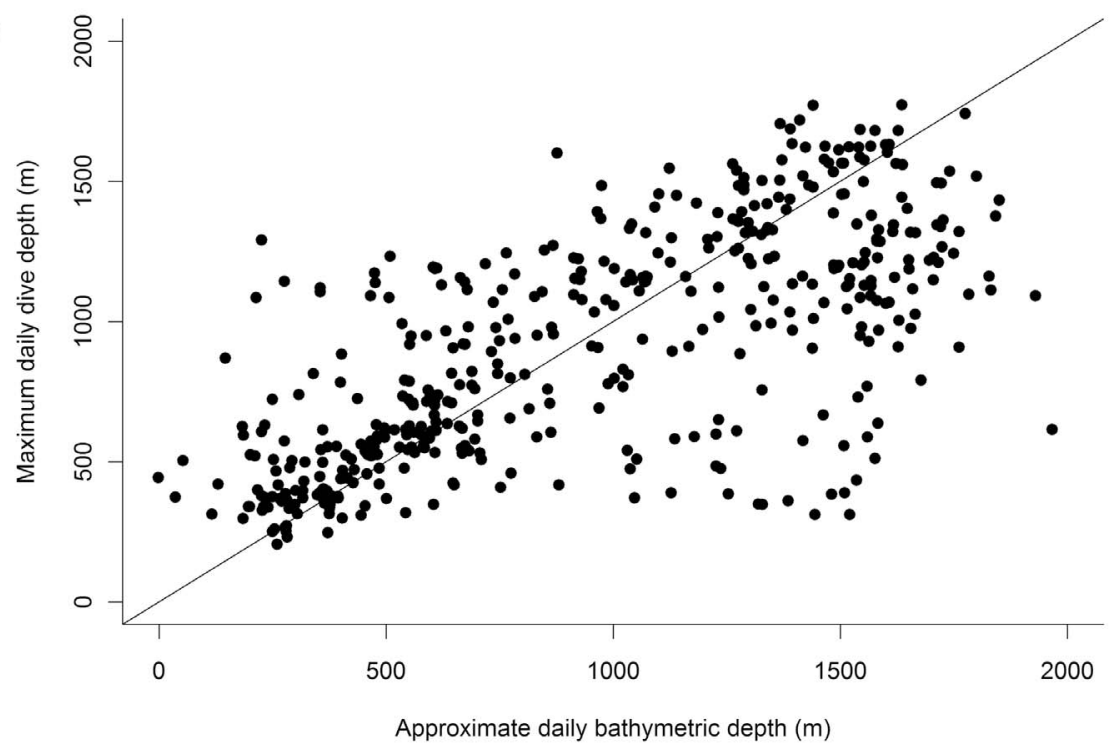

Figure 2 


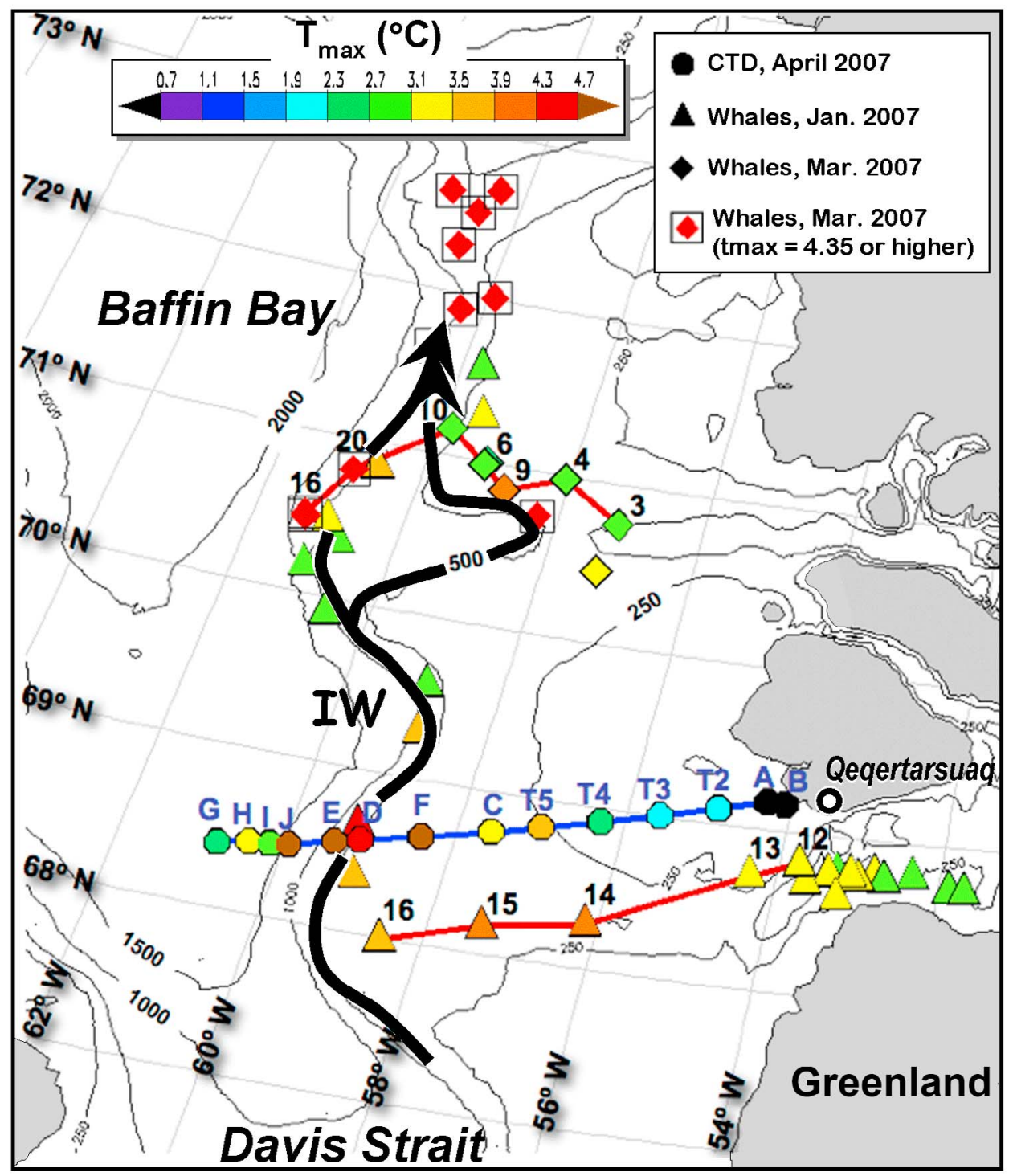

Figure 3. Locations of narwhal and CTD temperature sections. Symbols are color-coded by the maximum temperature of the profile. Squared narwhal stations have temperature maxima exceeding the sensor threshold $4.35^{\circ} \mathrm{C}$. The two synthetic narwhal sections (red lines, A and C) and the CTD section (blue line, B) are shown in Figure 3. The approximate pathway of Irminger Water (IW) is noted.

and 2007 remained on the eastside of Baffin Bay sampled north of $70^{\circ} \mathrm{N}$ (Figure 1). Overall, much of Baffin Bay was sampled by whales across the 3 year period with the exception of the deep basin between $72^{\circ} \mathrm{N}$ and $75^{\circ} \mathrm{N}$.

[14] Temperature and depth maxima were calculated for $100 \mathrm{~km}$ bins for whale profiles and examined in three regions: inshore Baffin Bay or bins that lie adjacent to the coast of West Greenland ( $n=7$ bins), offshore Baffin Bay or bins not bordering the coast of West Greenland ( $n=18$ bins), and Davis Strait or bins south of $65^{\circ}(n=3)$. When temperature maxima were identified, the depth at temperature maximum varied between about 260 and $1040 \mathrm{~m}$. For inshore Baffin Bay, temperature maxima were on average $3.0^{\circ} \mathrm{C} \pm 0.7^{\circ} \mathrm{C}$ with a range of $2.1^{\circ} \mathrm{C}-4.0^{\circ} \mathrm{C}$ that occurred at depths between 297 and $1040 \mathrm{~m}$. For offshore Baffin Bay, temperature maxima were on average $2.8^{\circ} \mathrm{C} \pm 0.6^{\circ} \mathrm{C}$ with a range of $1.5^{\circ} \mathrm{C}-4.3^{\circ} \mathrm{C}$ that occurred at depths between 266 and $568 \mathrm{~m}$.
In Davis Strait, the sample size was small; however, temperature maxima were on average higher, at $4.6^{\circ} \mathrm{C} \pm 0.1^{\circ} \mathrm{C}$, with a range of $4.5^{\circ} \mathrm{C}-4.6^{\circ} \mathrm{C}$ at depths between 381 and $579 \mathrm{~m}$.

\subsection{Helicopter-Based CTD}

[15] The ship and helicopter CTD hydrographic sampling of the cross section at $67^{\circ} \mathrm{N}-68^{\circ} \mathrm{N}$ (Figure 1) identified the well-known deep (between 200 and $400 \mathrm{~m}$ ) northward IW flow [e.g., Myers et al., 2009] along the West Greenland slope (Figure 3). This warm core extended westward from station T5 to station $\mathrm{J}$, or approximately $130 \mathrm{~km}$, reaching a maximum value of $4.85^{\circ} \mathrm{C}$ at $274 \mathrm{~m}$ depth at station $\mathrm{E}$ (Figure 4). The CTD data extended to $500 \mathrm{~m}$ depth, which was deep enough to capture the temperature maximum in that section. Although the warmest values were found along the slope, some relatively warm IW values also extended 

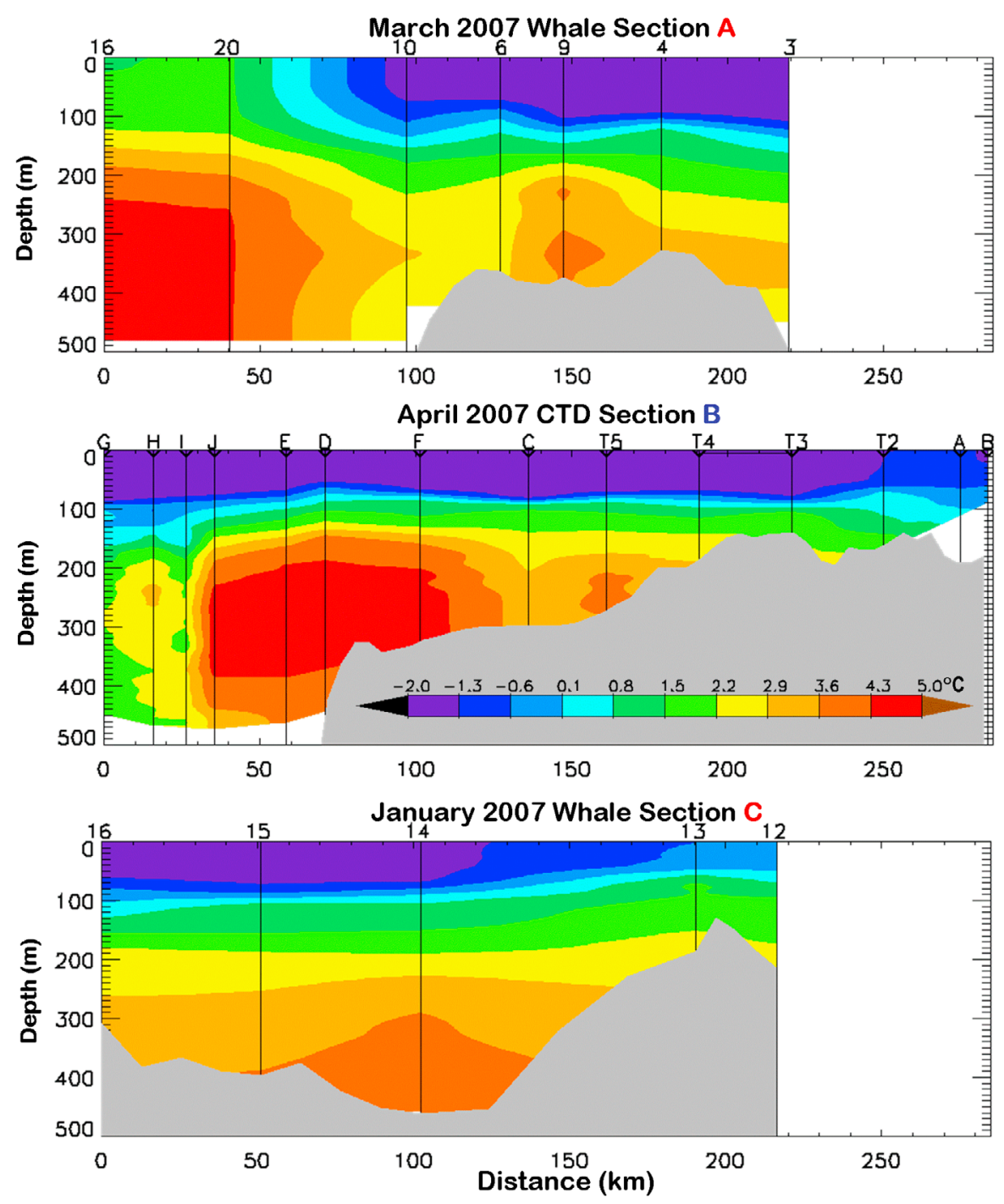

Figure 4. (top and bottom) Temperature sections using narwhal data and (middle) CTD data. See Figures 2 and 3 for location. The order of the sections proceeds from the northernmost section (A, taken in March) to the southernmost section (C, taken in January). Stations are noted at the top of each frame.

eastward onto the shelf along the CTD section but were limited by the shallow water west of Qeqertarsuaq (Figure 4).

\subsection{Comparison of Whale and CTD Data}

[16] The CTD section crossed the broad Greenland shelf and continental slope and terminated in deep central Baffin Bay in waters $>1500 \mathrm{~m}$ (Figure 4). Two whale "sections" parallel to the hydrographic section were constructed from whale movement and temperature data collected in January 2007 (south of the CTD section) and March 2007 (north of the CTD section), respectively (Figure 4). All of these data were collected well north of Davis Strait, a northern boundary for the complex circulations and recirculations within the Labrador Sea region.

[17] Temperature data from the three combined sections (two whales and one CTD) demonstrated relatively cool water near the surface and on the shelf (in contact with the overlying sea ice cover). Deeper waters were warmer, with a core of $4^{\circ} \mathrm{C}-5^{\circ} \mathrm{C}$ at $300-500 \mathrm{~m}$ depth, centered on isobaths between 300 and $1500 \mathrm{~m}$. The range in isobaths was notably large, probably reflecting the diverse origins of the warm core in the Arctic Ocean and Nordic and Irminger Seas. The basic structure and range of temperatures was similar in the CTD and whale sections, illustrating the utility of whale data to expand the single CTD section to a wider area.

\subsection{Whale Versus PHC Data}

[18] The mean winter IW temperature maxima (DecemberJanuary-February average) as measured by 2005-2007 whale data were compared with data from the Polar Science Center Hydrographic Climatology (PHC3.0 [Steele et al., 2001]). Baffin Bay data in PHC3.0 are largely based on summer cruises through the mid-1990s, with few winter data (http:// psc.apl.washington.edu/Climatology.html). A lack of winter data from central and western Baffin Bay created unrealistic upper ocean conditions in early versions of PHC, wherein 


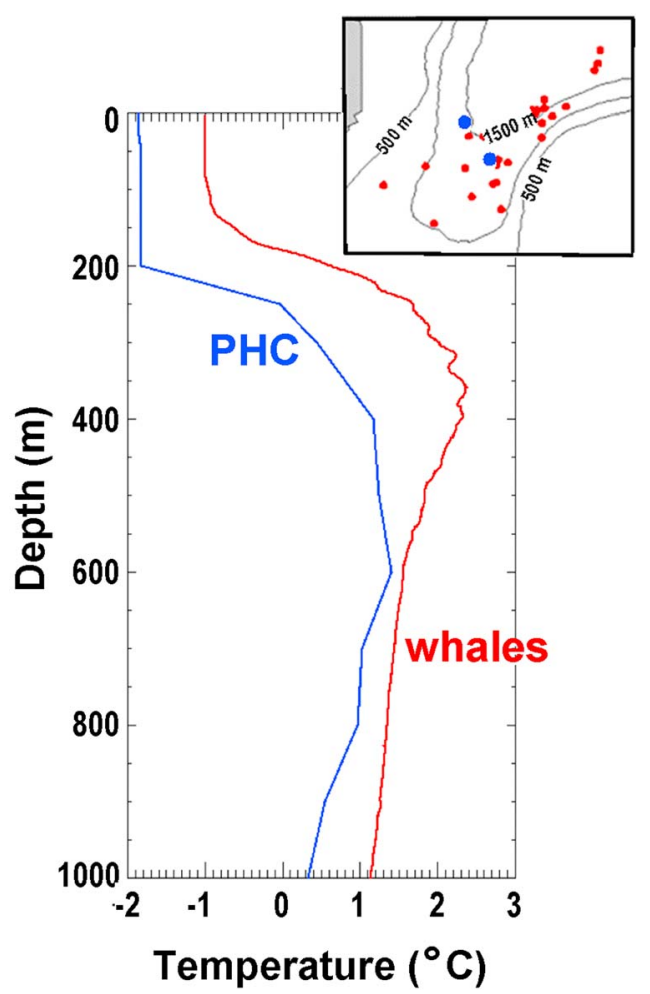

Figure 5. Comparison of temperature profiles in southern Baffin Bay (see inset) from PHC "engineered profiles" (blue) and from nearby February narwhal data (red).

the few observations from the WGC were extrapolated across the entire bay. In PHC2.0, this was addressed by "engineering" winter profiles in this region with values equal to those observed in the summer below $200 \mathrm{~m}$ depth and with the $200 \mathrm{~m}$ summer salinity extrapolated to the surface to simulate a deep winter mixed layer (set to the freezing point of this salinity). These profiles were then used in the optimal interpolation, which better confines the WGC waters to eastern Baffin Bay.

[19] Figure 5 shows a comparison of February whale data and nearby PHC "engineered" temperature profiles in southern Baffin Bay. The IW temperature maximum was warmer in the whale data, and the winter surface isothermal layer depth of $200 \mathrm{~m}$ assumed in the "engineered" profiles is too deep by $\sim 50-80 \mathrm{~m}$ (Figure 5). This could mean that PHC3.0, which represents mean conditions over the twentieth century, has an overly deep winter mixed layer in Baffin Bay. However, it might also reflect recent 21 st century change, i.e., shallower winter mixed layers arising from reduced convection associated with a warmer climate.

[20] It was also possible to compare the gridded spatial patterns of wintertime IW temperature maxima in PHC and whale data (Figure 6) as winter data were available along the West Greenland shelf and slope in both data sets. Both data sets showed the warmest water occurs in the southwest sector of the study area, reflecting the northward intrusion of IW. There was a good correlation between the whale temperature maxima and PHC temperature maxima in the $100 \mathrm{~km}$ bins (Figure 7); however, overall, the whale data were significantly on average $0.9^{\circ} \mathrm{C} \pm 0.6^{\circ} \mathrm{C}$ warmer than the $\mathrm{PHC}$ $(P<0.001)\left(R^{2}=0.5301\right)$. When this regression was con- ducted with a breakpoint of $2.5^{\circ} \mathrm{C}$ to examine contrast between cooler and warmer waters, the whale data were on average $0.96^{\circ} \mathrm{C} \pm 0.67^{\circ} \mathrm{C}$ higher than $\mathrm{PHC}$ values for cooler waters $\left(<2.5^{\circ} \mathrm{C}\right)$ and $0.69^{\circ} \mathrm{C}$ higher (standard deviation, 0.54$)$ than $\mathrm{PHC}$ values for warmer waters $\left(>2.5^{\circ} \mathrm{C}\right)$. The warming of whale IW temperature maxima, relative to PHC temperature maxima, showed no obvious spatial patterns and seemed to affect the bins in a random order. In central Baffin Bay, the difference of $\sim 1^{\circ} \mathrm{C}$ in whale (winter data) and PHC (summer data) temperature maxima might represent a warming trend, or it might reflect a mean seasonal difference. B. Curry et al. (Volume, freshwater, and heat fluxes through Davis Strait, 2004-2005, submitted to Journal of Physical Oceanography, 2010) report a similar amplitude for this seasonal difference in $500 \mathrm{~m}$ depth central Davis Strait mooring data in 2005; however, this is several degrees of latitude further south. In contrast, the whale-PHC difference of about $1{ }^{\circ} \mathrm{C}$ on the West Greenland shelf and slope are more likely to represent a true warming trend, as both data sets in this region are from winter. Thus, the whale data indicate that both IW and WGSW are warmer in recent years relative to data from climatology.

[21] There was no systematic bias between the change in depth and change in temperature when examined for each bin and there was no statistically significant relationship between the difference in temperature maximum for whalebased and PHC-based temperature data in each bin. An analysis of the depth of this temperature maximum revealed no large-scale coherent differences between the climatology and whale data. In other words, although the IW temperature maximum is clearly warmer in the whale data relative to climatology, the depth of this temperature maximum has not shifted significantly.

\section{Discussion}

[22] Our results suggest that the twentieth century warming of the WGC documented by Zweng and Münchow [2006] has continued during the past decade. We find that this warming is associated with a warmer WGC in both of its constituent water masses, i.e., both warmer IW and warmer WGSW. We also find a possible warming of central Baffin Bay subsurface waters, although this is difficult to confirm because the only historical data available for comparison are from the summer and recent evidence from further south in Davis Strait suggests possible seasonal shifts in the subsurface waters (Curry et al., submitted manuscript, 2009). Our results demonstrate that whale-obtained data can be used to make large-scale hydrographic surveys and to extend the spatial and temporal coverage of a historical database into the poorly sampled winter season.

[23] Water exiting Baffin Bay enters the Labrador Sea, one of the two or possibly three deep convection sites in the Northern Hemisphere [Pickart et al., 2002, 2003]. Warming of Baffin Bay may affect the water masses that reach the ventilation zone and could potentially result in a reduced water exchange in the Labrador Sea with large scale climatic consequences. A continued warming of Baffin Bay would also eventually affect sea ice coverage in the region that in recent years has retreated significantly [Heide-Jørgensen et al., 2009]. A further reduction in sea ice will reduce the surface albedo and cause increased warming due to solar 

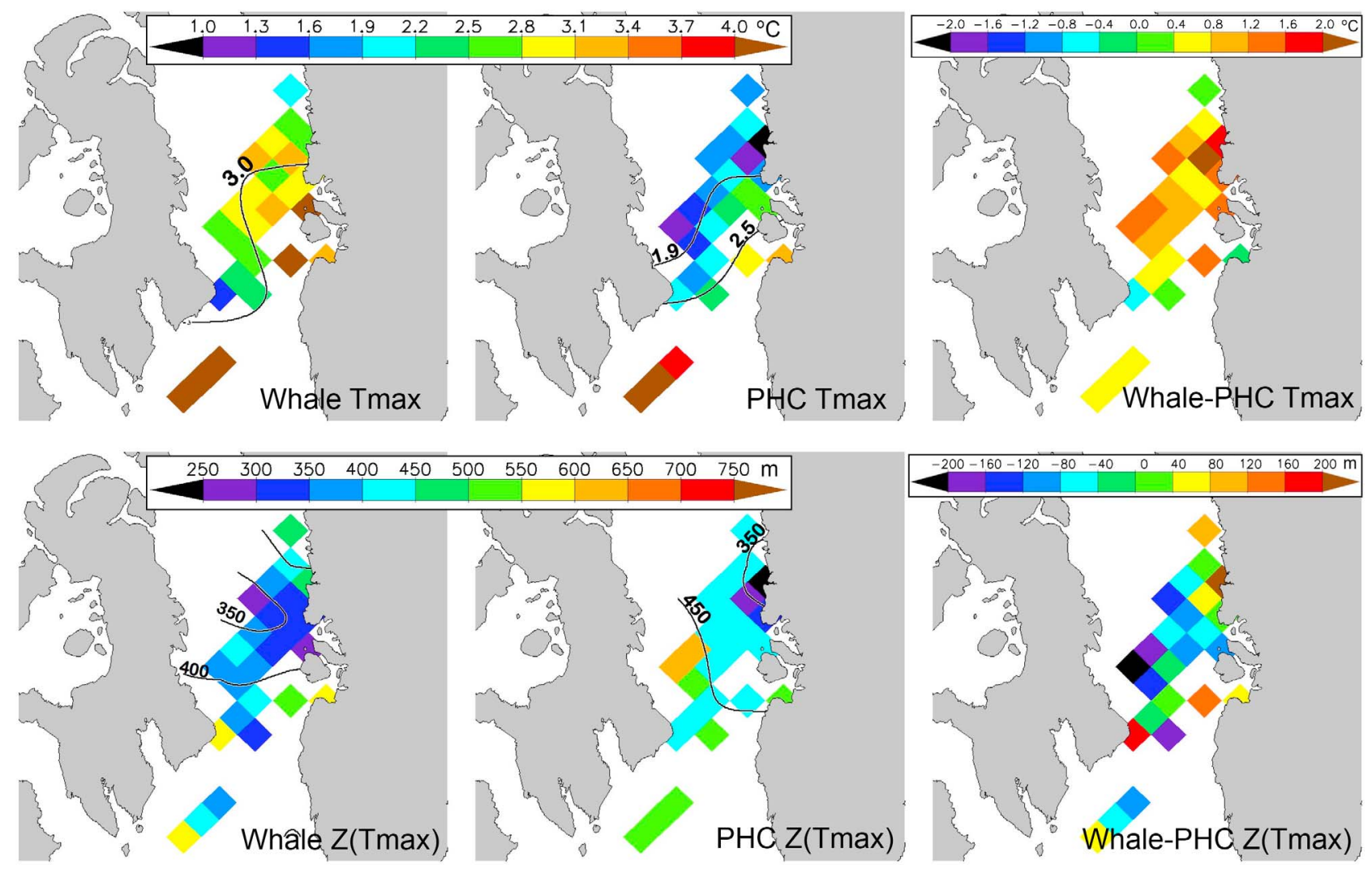

Figure 6. (top) The temperature maximum (Tmax) of profiles averaged into $100 \mathrm{~km}$ bins for (left) narwhal data, (middle) climatological data, and the (right) difference between the two for the months of December, January, and February. The climatological data are only shown for areas where narwhal data were available. (bottom) The depth at the temperature maximum for (left) narwhal data, (middle) climatological data, and the (right) difference between the two. There was no trend in $Z$. Contours represent smoothed spatial trends for the bins.

radiation. Thus, the observed hydrographic changes in Baffin Bay indicate a major and long-term alteration of the climate regime in the region. This shift will likely have pronounced effects on both the ventilation in the Labrador Sea and the species and ecosystems in Baffin Bay [Laidre et al., 2009; Heide-Jørgensen et al., 2009].

[24] Ecological effects of increased sea temperatures along the West Greenland coast have recently been demonstrated in the demography of large whale species [Laidre et al., 2009]. It is also well known the timing of sea ice break up and primary production bloom, both influenced by increasing sea temperatures or influx of IW, are important for the reproductive and foraging success of small whales [HeideJørgensen et al., 2009] and sea bird species [Laidre et al., 2008]. Possible ecological consequences of this continued trend include the potential for redistribution of the primary prey for the narwhal, the Greenland halibut (Reinhardtius hippoglossoides). Greenland halibut occur widely in Baffin Bay and are found at highest densities in areas with bottom temperatures $<2{ }^{\circ} \mathrm{C}$ [Laidre et al., 2004b]. With increased warming of Baffin Bay, Greenland halibut may expand their range northward or shift their primary distribution northward to stay in water masses within their preferred temperature range, similar to other forage fish species in West Greenland [Rose, 2005]. This may have consequences for narwhals,



Figure 7. Relationship between narwhal temperature maxima and PHC temperature maxima for twenty-seven $100 \mathrm{~km}$ bins in Baffin Bay and Davis Strait. 
which rely heavily on Greenland halibut at specific sites [Laidre and Heide-Jørgensen, 2005] and specifically select areas with cold bottom temperatures for foraging dives [Laidre et al., 2004b].

[25] The PHC database is used for numerical model initialization and validation by a wide range of institutes (e.g., the National Center for Atmospheric Research) and for largescale mean climatological descriptions of the high northern latitudes. The comparison presented here with recent whale data indicates that PHC deep temperature maxima within Baffin Bay are cooler than contemporary conditions by up to about $1{ }^{\circ} \mathrm{C}$. PHC also seems to overestimate the winter surface isothermal layer thickness by about $50-80 \mathrm{~m}$, possibly a result of weak winter convection in a warming climate. This is strong evidence of the utility of whale-based oceanographic data and should be considered in future updates of PHC or in any physical oceanographic studies of Baffin Bay.

[26] Oceanographers are increasingly realizing the importance of continuous monitoring for long-term modeling of climate processes. As a result, innovative remote samplers using instrumented marine predators are being developed [i.e., Lydersen et al., 2002; Fraser and Hofmann, 2003; Charrassin et al., 2008; Costa et al., 2008]. Diving ocean predators can be fitted with instruments that record the animal's location, diving depth, and concurrent oceanographic parameters creating a "real-time autonomous sampling platform" allowing for data collection from remote, ice-covered waters where sampling by conventional ship-based CTD casts is expensive or impossible. This offers a unique opportunity to collect data at relatively low cost from regions and seasons where traditional oceanographic measurements would otherwise be impossible, such as Baffin Bay.

[27] In summary, the whale data provided some of the first recent winter temperatures from Baffin Bay. The whale data values were similar to the CTD section taken nearby in space and time, although closer spatial intercalibration in future studies would be useful. The predictability of narwhal migrations and winter movements, their affinity to sea ice, repeated deep-diving in winter, and site fidelity are all qualities that make the species an ideal platform from which to obtain wintertime temperature data from Baffin Bay and West Greenland. Therefore, using knowledge of where different narwhal populations migrate and where they overwinter [Dietz et al., 2008], it is possible to tag narwhals from selected subpopulations and target specific water masses of Baffin Bay.

[28] Acknowledgments. Funding for fieldwork was provided by a NOAA Ocean Exploration grant to K.L.L. and M.P.H.J. and by the Greenland Institute of Natural Resources. We gratefully acknowledge support from the Arctic Sciences Section of the Office of Polar Programs at the National Science Foundation. Salary for K.L.L. was provided by the Applied Physics Laboratory at the University of Washington. Thanks are also extended to K. Eipe, P. Richard, J. Orr, H. C. Schmidt, Arctic Station of University of Copenhagen, and Air Greenland. We also thank R. Anderson, B. Curry, C. Lee, M. Ribergaard, and three anonymous reviewers for input, edits, and resources.

\section{References}

Becker, J. J., et al. (2009), Global bathymetry and elevation data at 30 arc seconds resolution: SRTM30 PLUS, Mar. Geodesy, 32, 355-371.

Bourke, R. H., V. G. Addison, and R. G. Paquette (1989), Oceanography of Nares Strait and northern Baffin Bay in 1986 with emphasis on deep and bottom water formation, J. Geophys. Res., 94(C6), 8289-8302, doi:10.1029/JC094iC06p08289.

Buch, E., S. A. Pedersen, and M. H. Ribergaard (2004), Ecosystem variability in West Greenland waters, J. Northw. Atl. Fish. Sci., 34, 13-28. Charrassin, J.-B., et al. (2008), Southern Ocean frontal structure and sea-ice formation rates revealed by elephant seals, PNAS, 105, 11,634-11,639.

Costa, D. P., J. M. Klinck, E. E. Hofmann, M. S. Dinniman, and J. M. Burns (2008), Upper ocean variability in west Antarctic Peninsula continental shelf waters as measured using instrumented seals, Deep-Sea Res. Pt. II, 55, 323-337.

Dietz, R., M. P. Heide-Jørgensen, P. Richard, J. Orr, K. L. Laidre, and H. C. Schmidt (2008), Movements of narwhals (Monodon monoceros) from Admiralty Inlet monitored by satellite telemetry, Polar Biol., 31, $1295-1306$.

Fraser, W. R., and E. E. Hofmann (2003), A predator's perspective on causal links between climate change, physical forcing and ecosystem response, Mar. Ecol.-Prog. Ser., 265, 1-15.

Harris, R. B., S. G. Fancy, D. C. Douglas, G. W. Garner, S. C. Amstrup, T. R. McCabe, and L. F. Pank (1990), Tracking wildlife by satellite: Current systems and performance, Fish and Wildlife Tech. Rep., 30, 52 pp., U.S. Fish and Wildlife Service, Washington, DC

Heide-Jørgensen, M. P., R. Dietz, K. Laidre, and P. Richard (2002), Autumn movements, home range and winter density of narwhals (Monodon monoceros) from Tremblay Sound, Baffin Island, Polar Biol., 25(5), 331-341.

Heide-Jørgensen, M. P., R. Dietz, K. L. Laidre, P. Richard, J. Orr, and H. C. Schmidt (2003), The migratory habits of narwhals, Can. J. Zool., 81(8), 1298-1305.

Heide-Jørgensen, M. P., K. L. Laidre, D. Borchers, T. A. Marques, H. Stern, and M. J. Simon (2009), The effect of sea ice loss on beluga whales (Delphinapterus leucas) in West Greenland, Polar Res., in press. Heide-Jørgensen, M. P., K. L. Laidre, M. L. Burt, D. L. Borchers, T. A. Marques, R. G. Hansen, M. Rasmussen, and S. Fossette (2010), Abundance of narwhals (Monodon monoceros) in Greenland, J. Mammal., in press.

Holland, D. M., R. H. Thomas, B. De Young, M. H. Ribergaard, and B. Lyberth (2008), Acceleration of Jakobshavn Isbræ triggered by warm subsurface ocean waters, Nat. Geosci., 1, 659-664.

Innes, S., M. P. Heide-Jørgensen, J. L. Laake, K. L. Laidre, H. J. Cleator, P. R. Richard, and R. E. A. Stewart (2002), Surveys of belugas and narwhals in the Canadian high Arctic in 1996, NAMMCO Sci. Publ., 4 , $147-190$.

Koski, W. R., and R. A. Davis (1994), Distribution and numbers of narwhals (Monodon monoceros) in Baffin Bay and Davis Strait, Meddelelser om Grønland Bioscience, 39, 15-40.

Laidre, K. L., and M. P. Heide-Jørgensen (2005), Winter feeding intensity of narwhals, Mar. Mammal Sci., 21, 45-57.

Laidre, K. L., M. P. Heide-Jørgensen, R. Dietz, R. C. Hobbs, and O. A. Jørgensen (2003), Deep-diving by narwhals, Monodon monoceros: Differences in foraging behavior between wintering areas? Mar. Ecol. Prog. Ser., 261, 269-281.

Laidre, K. L., M. P. Heide-Jørgensen, O. A. Jørgensen, and M. Treble (2004a), Deep-ocean predation by a high Arctic cetacean, ICES J. Mar. Sci., 61, 430-440.

Laidre, K. L., M. P. Heide-Jørgensen, M. L. Logsdon, R. C. Hobbs, P. H. Heagerty, R. Dietz, M. T. Treble, and O. A. Jørgensen (2004b), Seasonal habitat associations of narwhals in the high Arctic, Mar. Biol., $145,821-831$

Laidre, K. L., M. P. Heide-Jørgensen, J. Nyland, A. Mosbech, and D. Boertmann (2008), Latitudinal gradients in sea ice and primary production determine Arctic seabird colony size in Greenland, P. Roy. Soc. B, 275, 2695-2702, doi:10.1098/rspb.2008.0874.

Laidre, K. L., P. Heagerty, M. P. Heide-Jørgensen, L. Witting, and M. Simon (2009), Sexual segregation of common minke whales (Balaenoptera acutorostrata) and sex ratio of catches in Greenland, ICES J. Mar. Sci., 66, 2253-2266.

Lydersen, C., O. A. Nøst, P. Lovell, B. J. McConnel, T. Gammelsrød, C. Hunter, M. A. Fedak, and K. M. Kovacs (2002), Salinity and temperature structure of a freezing Arctic fjord-Monitored by white whales (Delphinapterus leucas), Geophys. Res. Lett., 29(23), 2119, doi:10.1029/ 2002GL015462.

Myers, P. G., N. Kulan, and M. H. Ribergaard (2007), Irminger Water variability in the West Greenland Current, Geophys. Res. Lett., 34, L17601, doi:10.1029/2007GL030419.

Myers, P. G., C. Donnelly, and M. H. Ribergaard (2009), Structure and variability of the West Greenland Current in summer derived from six repeat standard sections, Prog. Oceanogr., 80, 93-112, doi:10.1016/ j.pocean.2008.12.003. 
Pickart, R. S., D. J. Torres, and R. A. Clarke (2002), Hydrography of the Labrador Sea during active convection, J. Phys. Oceanogr., 32(2), 428-457.

Pickart, R. S., F. Straneo, and G. W. K. Moore (2003), Is Labrador Sea Water formed in the Irminger Basin? Deep-Sea Res. Pt. I, 50(1), 23-52.

Ribergaard, M. H., S. M. Olsen, and J. Mortensen (2008), Oceanographic investigations off West Greenland 2007, NAFO Sci. Counc. Doc., 08/003.

Richard, P. R., J. L. Laake, R. C. Hobbs, M. P. Heide-Jørgensen, N. C. Asselin, and H. Cleator (2010), Baffin Bay narwhal population distribution and numbers: Aerial surveys in the Canadian High Arctic, 2002-2004, Arctic, in press.

Rose, G. A. (2005), Capelin (Mallotus villosus) distribution and climate: a sea "canary" for marine ecosystem change, ICES J. Mar. Sci., 62, 1524-1530.

Simmons, S. E., Y. Tremblay, and D. P. Costa (2009), Pinnipeds as oceantemperature samplers: Calibrations, validations, and data quality, Limnol. Oceanogr., 7, 648-656.

Smith, E. H., F. M. Soule, and O. Mosby (1937), The Marion and General Greene expeditions to Davis Strait and Labrador Sea, Bull. U.S. Coast Guard, 19, 199 pp.
Steele, M., R. Morley, and W. Ermold (2001), PHC: A global ocean hydrography with a high-quality Arctic Ocean, J. Climate, 14, 2079-2087. Stein, M. (2004), Climatic overview of NAFO Subarea 1 1991-2000, J. Northw. Atl. Fish. Sci., 34, 29-40.

Stein, M. (2005), North Atlantic subpolar gyre warming-Impacts on Greenland offshore waters, J. Northw. Atl. Fish. Sci., 36, 43-54.

Tang, C., C. K. Ross, T. Yao, B. Petrie, B. M. DeTracey, and E. Dunlap (2004), The circulation, watermasses and sea-ice of Baffin Bay, Prog. Oceanogr., 63, 183-228.

Zweng, M. M., and A. Münchow (2006), Warming and freshening of Baffin Bay, 1916-2003, J. Geophys. Res., 111, C07016, doi:10.1029/ 2005JC003093.

W. Ermold, K. L. Laidre, and M. Steele, Polar Science Center, Applied Physics Laboratory, University of Washington, 1013 NE 40th St., Seattle, WA 98105, USA. (klaidre@apl.washington.edu)

M. P. Heide-Jørgensen, Greenland Institute of Natural Resources, PO Box 570, 3900 Nuuk, Greenland. 